Schaffer, A. J., and Avery, M. E. (1971). Diseases of the Newborn, 3rd ed., p. 136. Saunders, Philadelphia, London, and Toronto.

Smith, B. T. (1972). Isolated phrenic nerve palsy in the newborn. Pediatrics, 49, 449.

D. Anagnostakis, ${ }^{\star}$ C. Economou-Mavrou, A. Moschos, P. Vlachos, and D. LiakaKos

Department of Paediatrics, Athens University; and the Second Paediatric Clinic, Children's Hospital 'Aglaia Kyriakou', Athens, Greece.

*Correspondence to Dr. D. Anagnostakis, 'Aghia Sophia' Children's Hospital, Athens 608, Greece.

\section{Treatment with new synthetic analogue of vasopressin in diabetes insipidus}

The aims of treatment of diabetes insipidus are replacement therapy with a vasopressin preparation, ancillary use of chlorpropamide or thiazide diuretics in some cases, and eradication of the underlying cause of the condition where appropriate. Replacement therapy only will be considered in this communication. This poses several problems. Pitressin snuff may cause local complications such as chronic rhinitis as well as pulmonary problems, for example bronchospasm and pulmonary fibrosis; lysine vasopressin nasal snuff has the disadvantage of a short duration of action. Injections of pitressin may result in physical pain and psychological upset, as exemplified in this case; also, preparation of the solution is crucial in order to prevent administration of the inert vehicle in the absence of the active pitressin.

DDAVP (1-deamino-8-D-arginine vasopressin) has been claimed to possess a higher antidiuretic potency and a longer duration of action than the vasopressin preparations currently in use. Andersson and Arner (1972) reported success with DDAVP in the management of 10 adult patients with cranial diabetes insipidus of various aetiologies, but no similar experience has been reported in children.

\section{Case report}

A previously very healthy girl, now aged $10 \frac{1}{2}$ years, presented in 1969 with a 3-month history of polyuria and polydipsia. She had sustained no obvious head injury and she did not complain of headache, vomiting, or convulsions; there were no other urinary tract symptoms. There was a negative family history of diabetes mellitus and polyuria and/or polydipsia.

On examination she appeared a normal, well looking girl with satisfactory hydration. The fundi and visual fields were normal, as was the remainder of the CNS, and the respiratory, cardiovascular, and gastrointestinal systems.

There was no glycosuria. Repeated examinations of the urine failed to reveal any evidence of urinary tract infection. An accurate fluid balance showed that her average fluid intake was 2-2 $\frac{1}{2} 1$. daily and that her urinary output was 2-3 1./day. A fluid deprivation test was carried out lasting 15 hours; her urinary output continued at a high level. The highest urinary specific gravity during the test was 1008 and she lost $1.8 \mathrm{~kg}$ in weight. She was then given an intravenous infusion of hypertonic $(2.5 \%)$ saline over 45 minutes; there was no significant change in urinary output or in urinary specific gravity. Pitressin 0.1 unit was injected intravenously and the urinary flow fell from a pre-injection level of 3.8 $\mathrm{ml} /$ minute to $1.0 \mathrm{ml} / \mathrm{minute}$; the highest specific gravity obtained was 1011. Full blood count, blood urea, serum electrolytes, calcium, inorganic phosphorus, alkaline phosphatase, proteins, and electrophoresis were all normal. Skull $x$-ray, CSF, EEG, and air encephalography detected no abnormality.

It was concluded, therefore, that this girl was suffering from idiopathic pituitary diabetes insipidus.

Therapy was started with injections of pitressin tannate in oil, as well as lysine vasopressin nasal spray four times daily. The patient refused to administer the spray a short time after its introduction. Initially she required one injection every 3 or 4 days, her symptoms being well controlled on such a regimen. It soon became obvious that injections were required more frequently, i.e. on a daily basis. With this came many psychological problems which were extremely difficult to overcome.

A supply of DDAVP was obtained and the patient was readmitted for a trial of therapy. The last dose of pitressin tannate in oil was injected the day before admission (point $\mathrm{A}$ in Fig.) $\mathrm{A}$ fluid balance chart was constructed; simultaneous serum and urine specimens were obtained on several occasions for estimation of osmolality; the specific gravity of all urine specimens was measured. Three doses of $7.5 \mu \mathrm{g}$ DDAVP were administered on day 4 (point $B$ in Fig.) and no further drug was given until day 8 (point $C$ in Fig.).

\section{Results}

The results are set out in the Fig. On days 1 and 2 it was noted that the patient was concentrating her urine satisfactorily, presumably as a result of the pitressin given before admission. On day 3 the urine osmolality fell below that of the serum, indicating that she had little circulating antidiuretic hormone. On day 4 the patient was given three doses of DDAVP and urine osmolality (and specific gravity) increased with a corresponding decrease in her fluid intake and output. This effect was noted also on day 5 , indicating that the DDAVP was still operating up to 24 hours after the previous dose. 


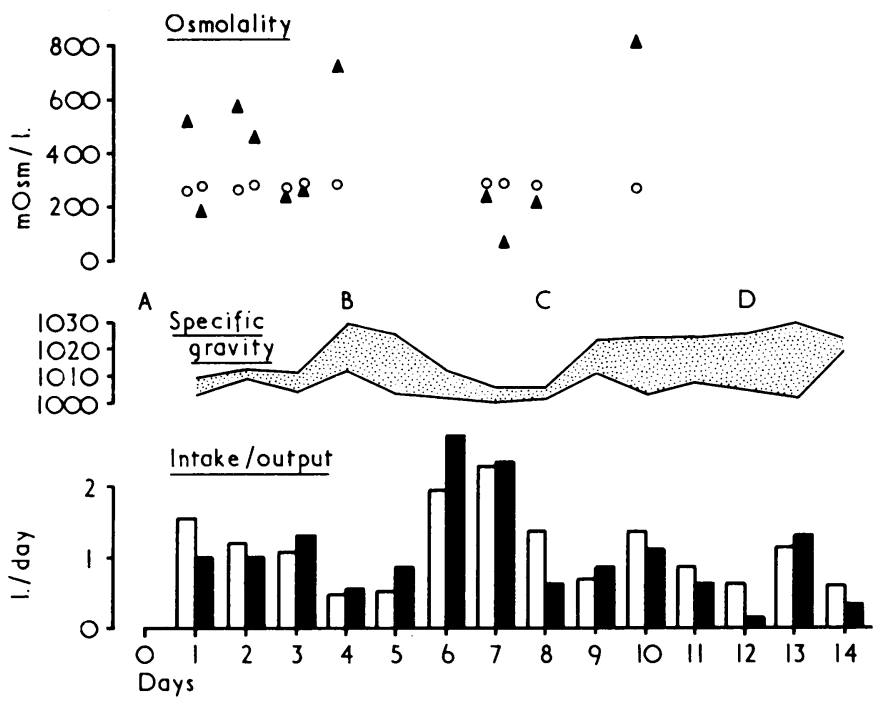

Fig.-Progress of the patient before and during treatment with DDAVP. $\Delta$ urine osmolality, $\bigcirc$ plasma osmolality. Stippled area is range of urinary specific gravities. Open columns show daily fluid intake, solid columns show daily urinary output.

The drug was withheld for several days and the patient's symptoms recurred. Treatment was started again on day 8 (point $\mathrm{C}$ in Fig.) and was thereafter continued. She was able to concentrate her urine satisfactorily on a schedule of $5 \mu \mathrm{g}$ DDAVP twice daily. No side-effects were noted, and the patient easily administered the preparation with confidence. The patient has since remained well.

\section{Discussion}

DDAVP is a new synthetic analogue of vasopressin administered intranasally via a plastic nasal catheter ('rhinyle'). A measured quantity of a solution of the preparation is collected in the 'rhinyle', one end of which is inserted through the anterior nares; the other end is placed between the lips, and the patient then blows the contents of the 'rhinyle' onto the nasal mucosa, from where the substance is absorbed.

In view of its ease of administration, freedom from side effects, and relatively long duration of action, DDAVP seems to be a useful preparation in the treatment of pituitary diabetes insipidus in children.

\section{Summary}

Idiopathic pituitary diabetes insipidus in a 10year-old girl was successfully treated with a new synthetic analogue of vasopressin, 1-deamino-8-Darginine vasopressin, given intranasally.
I am grateful to Dr. G. M. Komrower for permitting me to present his patient, and to Ferring Pharmaceuticals, Sweden, who supplied the DDAVP.

\section{REFERENCE}

Andersson, K. E., and Arner, B. (1972). Effects of DDAVP, synthetic analogue of vasopressin, in patients with cranial diabetes insipidus. Acta Medica Scandinavica, 192, 21.

\section{HARRY NASH *}

Royal Manchester Children's Hospital, Pendlebury, Manchester.

^Correspondence to Dr. H. Nash, St. Mary's Hospital, Hathersage Road, Manchester M13 0JH.

\section{Oesophageal atresia}

\section{3 cases in 2 generations}

We report what we believe to be the second recorded case of oesophageal atresia in parent and child. Engel et al. (1970) described a woman, one of their first successfully-treated patients, whose daughter was also affected. Both had oesophageal atresia with a tracheo-oesophageal fistula to the lower oesophageal pouch. This combination of anomalies is generally known as oesophageal atresia type III, and accounts for 85 to $90 \%$ of patients (Freeman, 1969). 